\title{
Determining the Cultural Identity of a Child through Folk Literature
}

\author{
Ekaterina P. Stavrou* \\ Doctor of University of Ioannina Greece, Special Educator, Kindergarten teacher Scientific associate- Instructor at Technological \\ Institute of Epirus, Ioannina (Greece) \\ *Corresponding author: kstavrou@cc.uoi.gr
}

Received March 23, 2015; Revised April 02, 2015; Accepted April 12, 2015

\begin{abstract}
The concept of cultural identity is characterized by many dimensions and being investigated in several studies of culture and many social theories. Cultural identity is recognized and determined through the interplay of different identifying elements such as location, language, ethnicity, myths, religious culture, history, art and traditions that make up the national cultural heritage. Folk Literature is a prime scientific area through which a child develops his identity and physiognomy, as it points out the diverse nature of things during the pedagogical process. This fact should be taken into account by educators so that they can substantially and effectively guide children to find real truth and knowledge and, at the same time, realize their true essence through tradition. Therefore, tradition, which involves the cultural heritage of centuries, has the power to consciously or unconsciously penetrate into the soul of a child, which shapes his identity at an immature stage of development. Our intervention focuses on folk tales, folk songs, proverbs, myths and legends.
\end{abstract}

Keywords: child, cultural identity, folk culture, folk literature

Cite This Article: Ekaterina P. Stavrou, "Determining the Cultural Identity of a Child through Folk Literature.” American Journal of Educational Research, vol. 3, no. 4 (2015): 527-534. doi: 10.12691/education-3$4-20$.

\section{Introduction}

The term "Culture" in general refers to the transmittance of social elements from generation to generation, a process that is achieved through social mechanisms such as family and school.

Each people displays some unique identifying features, some characteristic elements of its culture, the assimilation of which constitutes its cultural identity distinguishing them from other people.

Cultural identity is recognized and determined through the interplay of different identifying elements such as location, language, ethnicity, myths, religious culture, nations, history, art and traditions (such as songs, traditional costumes, dietary habits) that make up the national cultural heritage. Consequently, the concept of cultural identity takes on many dimensions and becomes the subject of investigation from the perspective of both culture and social theories.

However, the formulation and conservation of the cultural identity of a child takes place mostly within the educational process and through the connection of the child to language. Therefore, common and longstanding tradition [24], constitutes the basis upon which cultural identity is formed, and the best time to build upon such are the preschool years and the first years of primary school.
Folk Literature is a prime area within which a child realizes his identity and physiognomy, as it brings to the surface the diverse nature of things during the pedagogical process, a reality that should be taken into account by educators so that we can substantially and effectively guide children to find real truth and knowledge and, at the same time, help them see themselves for who they really are through tradition [29].

\section{Folk Culture and the Creation of Cultural Identity}

Folk culture is defined as a set of features, which, along with the elements comprising national culture, determine the identity of a people. Folk culture is privileged not to be limited to the geographical boundary of a state, but constitutes an identifying element among related groups that may be separated by long distances. This shows the role folk culture plays as the agent of historical continuity and gives meaning to the necessity of the preservation of an identity. Identity - through tradition - comprises a unique construct that has been created through time from the distillation of historical events, poetry, art and fiction.

The main constituting factors for the creation of the cultural identity of a people include the dominant national group, social structures, history, culture, language, religion, the political-legal system, economic development, education and the media [22]. The four criteria that play a dominant role in the formation of an identity are: i) 
ideology, ii) historiography that is associated with national reference, iii) literature that processes, regenerates, dramatizes and narrates daily life and iv) language, which is the main tool of socialization [15].

A child grows and assimilates cultural elements from his cultural heritage, i.e. the "culture" and wisdom of the people to which he belongs, formulating thereby his cultural identity. The development of a child's cultural identity is also directly impacted by the process of socialization of the child within the particular cultural group in which he lives. Thus, a child forms a cultural identity, which depends each time on the group with which the child interacts at any given time, as folk culture - and culture in general - is that identity which is formed by the structural incorporation of cultural influences of other people, assuming thereby new outlooks [29]. Therefore, folk culture is an important factor for the outline of the concept of cultural identity, which seals and keeps alive the soul of a people.

Let's examine how cultural identity is formed in a child: a child between the ages 6 and 12 years old undergoes many biological and cognitive changes during development. Social changes follow suit in the process as the child moves from the state of being supervised by his parents to the school environment and the broader social context where peers play an increasingly important role in defining his sense of self- identity. Within this social context, the identity of a child develops by his participation in the group [23]. The identity of a child is part of his total personality. The child's cultural identity is part of his identity, which has an ideological or interpersonal character and forms during the child's evolutionary preschool age and is determined during adolescence [11]. A child learns, appropriates and becomes accustomed to his cultural heritage, a process that has a positive effect on his self-esteem and socioemotional adjustment. Therefore, the completion of the process of the formation of a child's cultural identity is analogous to the process of the formation of his personality.

Cultural identity refers to the harmonious coexistence of the tradition and values of two or more cultural groups. The child learns to love his folk culture, to accept and realize his unique identity and to respect other people's cultures; guided through this knowledge, he finds himself on the path of self-knowledge.

What is the process of this development in a child?

As we know from developmental psychology, the way by which young children approach knowledge - except the persistent way of logical correlations - is the way of emotional intelligence. When the child's imagination is also at play, this way becomes infinitely shorter and the knowledge built becomes established because of its vivacity.

When referring to emotional intelligence, we mean the logic of the heart, i.e. "the emotional mind", aptly described by Freud in the concept of the "primary process". This is the logic of religion, poetry and myths in children; it is a primary thought process in which everything is possible. Great spiritual teachers, such as Christ, touched the hearts of their students communicating with them through the language of emotions, teaching with parables, myths and stories, expressing themselves in the language of the heart, the symbols of which (religious, ceremonial) do not have or carry insignificant meaning from a logical point of view. Consequently, emotional intelligence correlates the elements it receives, which symbolize a reality or recall the memory thereof, considering them the real thing, within the frame of timelessness and free from the cause-effect relationship [29].

German educator and researcher Chichelberger, $\mathrm{H}^{1}$, claims that folk tales are strongly imprinted on the early memories of a child. According to her study, the brain is organized on the basis of its own previous experiences. This means that the central nervous system is subject to a building plan that is not watertight, i.e. it may develop when interacting with the environment. Through this interaction, the child acquires experiences that evolve and grow within the environment and through the child's reactions to the environment, so that new experiences are added to older ones. For example, folk tales are experienced by children as true reality, which has the power to cause them to feel joy or anxiety. With their repetition, however, a child recognizes that these exist only in the imagination as older memory data, either already experienced or in the area of the subconscious. These imaginative elements correspond to previous experiences existing within the children. We could say, thus, that children find a way to play in order to face difficulties and ultimately win, ridding themselves of inherent stress.

The living language of folk literature constitutes thus the foundation of the Modern Greek self-consciousness, as the composition of language and folk creation expresses the qualitative strength of a nation's spiritual presence. The use of folk language through tradition forms the historical consciousness of the child and leads to cultural unity, by its direct relationship to the ancient Greek world and Byzantium [30].

In Greek textbooks of primary school ${ }^{2}$ and in the subjects of the curricula of pre-school education, there are contained a host of traditions, folk tales, fables, riddles, proverbs and folk-sayings, which help the child's mind to understand the deeper meaning of words as well as the multifaceted and multidimensional use thereof.

\section{The Greek Folk Literature}

According to anthropology, man began as a "speaking man" (homo loquens) and became - with the invention of the written word - a "writing man" (homo scribens). The priority in language belongs unquestionably to the spoken word, hence the thought and the language of "homo sapiens" must have been initially poetic, i.e. intensely emotional. Language, hence, followed the mythical thinking that was typically inclined to personify the world and to use metaphors and other similar means [3].

We focus our attention on the dynamic role of folk literature in which there is an intrinsic and essential content defined by the common origin or also by the common structure of experience (common modalities and forms of life). Folk literature has an oral origination since

\footnotetext{
${ }^{1}$ She was Max Luthi's assistant. See at: Tsitslspergker, Helga, Children playing tales, [in Greek], Athens: Patakis, 1995.

${ }^{2}$ There are many topics indicated by our tradition, for preschool education.
} 
its beginning; it is the ancestral heritage, which people produce and use in the oral form, but also in the written form of an oral origination, which is the precondition for its genuineness. It is a constantly changing and evolving cultural creation which calls to mind previous historic times. It includes lore, tales, narratives, teachings, myths, legends, proverbs, jokes and riddles ${ }^{3}$. In English these go under the heading "folklore" and in German "sage". Folklore is an international phenomenon: we know about the legends of the Greco-Roman, Egyptian and Babylonian periods and, partly, the Indian and Chinese antiquity, through literature: the poems of Homer, the tragedies of Sophocles, the works of Virgil and Ovid.

Folk literature, being a historical phenomenon, has encountered profound social realities over time and adapted them. Oral tradition characterizes a certain phase of culture, which is related to the level of societal evolution. Certainly, any radical change in the way of life of a place (e.g. war) is reflected on its folktale, which draws matters from everyday life, albeit it moves within the realm of fiction.

Consequently, folktale passed down from generation to generation and the wisdom of culture and the lessons thereof passed onto the child, making him a member of society. All the elements of a society are reflected on folk literature such as the beliefs of society, language, philosophy, dance, art, music, traditions, manners and customs that originate from the accumulated experience of a society [29]. Their contents may be used primarily as entertainment reading, but also as cultural material that will contribute to the shaping of contemporary identity of the new generation.

Narrative in its ancient art form encompasses the transfer of the collective memory that holds universal values-guides for daily life in a world that is changing rapidly and radically, and may occasionally offer solutions in times of great crises and structural changes at both individual and collective social levels [19]. Therefore, the facts that we give in this article are universally valid as folk literature has (according to theory) common structure and is genetically related to ritual while it operates within the society.

This paper focuses on the Greek reality. The search of the beginning of the Modern Greek folk literature - based on the use of folk language - is detected in the new social reality that is formed in the $9^{\text {th }}$ and $10^{\text {th }} \mathrm{C}$. after the Byzantine Empire lost its eastern provinces. This reality resulted in the strengthening of the population of Greek origin or people who thought themselves Greek, a fact that is reflected on the new poetry that shifts from the commitment to classical education, which was dominant in the higher ranks of Byzantium [30].

\subsection{Myth}

The myth predates the tale, according to Propp: «therefore, we can include the myth as a possible source of the fairy tale» [27] ${ }^{4}$. Myths are an inexhaustible source

\footnotetext{
${ }^{3}$ About riddles see the source: Hatzidaki- Kapsomenou (2000) Modern Greek gold thesaurus riddles, Heraklion: University of Crete.[in Greek].

${ }^{4}$ Propp argues that the myth cannot be separated from the magical tale, thus the magical tale should be compared to the myths of ancient civilizations as well as those of primitive societies. The concept of the historical past is the foundation of Propp's research about the comparison and the study of the tale.
}

of ideas, humanitarian values and poetry. When we say "myth", we mean a tale about divine beings, heroes and demigods in which people believed. Faith is not a psychological factor but a historical one. For example, the myths about Hercules are closely related to the magical fairytale; however Hercules was a deity, the subject of a cult.

Furthermore, myths offer explanations about life and contribute to the preservation of human statutes, because they can operate at metaphysical, cosmological, sociological and psychological levels, related to the shaping of an individual in accordance with the objectives and ideals of the individual's social group [6].

Myths are an integral part of life of ancient Greeks as they complement their cultural portrait. All the aspects and events of their lives can be understood given the mythological background of their thought process.

So, myths were born due to many cultural needs [12]; in other words, myths meet cultural needs as they "activate" the cultural structures or the identity of a tribe, a city or a nation, linking it to universal truths. Life's force that is contained in the myths constituted the basis of ancient philology and was shown to be, through its use in literature, the most important means of expression. The channel, through which the myths' usefulness is transmitted to the child, is pride for the accomplishments of the ancestors, as he is led to becoming acquainted with them through the myths. Such myths are: Aesop's Fables, the Homeric epics, the twelve gods of Olympus, the Argonauts, demigod Hercules, Dedalus, (the first aviator), the Trojan War, the myth of Persephone, Oedipus and the Sphinx, the gnomes of Modern Greek tradition and many others.

The child associates values, virtues, beauty, morality, high morals, as well as the concepts of welfare and death for every living creature through myths. They are, in other words, the wardens of the moral system and values, because they serve truth, humanity and beauty. For example, Aesopian's myths which include the extract of the wisdom and experience of centuries, are shown to have great timeless pedagogical value. The constituent elements thereof, such as simplicity and allegory, promote good patterns of behavior for the child; they teach moral values like altruism and the right attitude towards nature and the environment in general.

According to the structural analysis, myths are a symbolic communication system analogous to the linguistic system. Both systems represent symbolically an objective reality. Thus, through the analysis of myths (the study of their substructure) we can see the problems of a society, while at the same time, the society itself can resolve these problems.

Claude Lévi-Strauss pointed out - studying the thought process of people who did not know how to write- that every myth has a complex logic that attempts to explain the above problems. A myth is made up of various figures, patterns, motions of life that one encounters in societies of hunters and farmers. These expressions of life and various objects, animals and plants encountered in myths, have their own symbolic significance and function in the mythical world and the cultural traditions of a society. [28] Consequently, in the mythical thinking - people, things and their interrelationships acquire a symbolic content and "social norms are better suited to the instinctive order of 
nature of primitive people”. [6] Primitive man bases his explanation of the habits of the existing world's structure on mythological ideas. Correspondingly, man joins the tradition, which defines the specific type of the explanatory idea that matches his psychological predisposition [4].

\subsection{Folk Tales}

Folk tales are the main narrative genre of folk literature; it is the subject of study for research in the areas of folklore, literature, anthropology, psychology and pedagogy.

Folk tales introduce the child to the history of the literary text but also to his personal history and thereby constitute perfect intellectual food [20], so this catalytic effect of the folktale assists in the socio-emotional development of the child. Therefore, tales help mobilize and operate the symbolic activities of the mind that people use to construct meaning not only of the external world around them but also of themselves, through reflection [5].

Ordeals and labors are key components of folktales. Upon the completion of feats, the folktale's hero wins and feels vindicated. The folktale chooses the folk heroic model and promotes the substantial aspect of the moral and social justice of the folk narrative [31]. The ordeal (athlos in Greek) emerges as a functional, dynamic and anthropomorphic expression of a complex semantic structure that includes both negative and positive aspects [14]. Ordeals are necessary because every man wants to face some dangerous situations, some tests, and make his way through the world. A child experiences all these things in his imagination on listening or reading folktales.

The struggle against grave hardships of life is an inescapable reality, an essential part of human existence, but if one shows courage and fights against the unexpected and often unjust ordeals, then he shall prevail and ultimately win. The final victorious outcome conveys the message that the child who wants to be himself, reach wholesomeness and secure his identity, must go through these ordeals, face dangers and win battles [3]. These ordeals and face-offs of the child with dangers, imaginative monsters and general personifications of evil are necessary at the level of imagination that is offered in the tale for the child to ultimately grow into a mentally and psychologically mature adult.

Tales suggest notions or imply solutions but never name them as they reflect the basic psychological structures of man to a greater extent than other types of folk literature. They allow the child to imagine the way in which he will apply to himself all that is revealed in the tales about life and human nature.

The folktale, though seeming at first as completely distant from reality, is often experiential in nature. The magical is clothed continuously with realistic details, and tales ultimately substantiate the lifestyle and the moral codes of the community. They incorporate the past to the present as a source of useful knowledge.

Jung evaluated the tales and the mythical symbols as sources of wisdom. According to him, the world of the human spirit and the world of impulses [17] have been introduced and expressed in tales. Folktales allow the child to identify with archetypal situations and experiences, such as the conflict between good and evil, the difference between courage and cowardice and the use of information as weapon against force. They help eradicate feelings of isolation and loneliness, to which children are vulnerable, making them feel part of a large group [7].

A folktale's transformations reflect the evolution of morals and lifestyle's trends and are its most important elements. A folktale has the steady ability to adapt the most magical elements, the new narrative data of a society.

The first international tale directory was compiled by Antti Aarne and Stith Thompson in 1928, and it is a classification system of tales based on patterns. The list was expanded with the contribution of Dundes, Alan; subsequently, it was published in German by Uther, Hans Jörg (Munchen, New York: 1981), and revised and republished by the latter in 2004 and finally in 2011.

The directory of Greek tales is modeled after the international directory and was inaugurated by Nicholas Politis with the founding of the Folklore Society in 1909. Politis laid the foundation for the beginning of a systematic collection and publication of Greek traditional tales; he was succeeded by George Megas, and then the team of Michael Meraklis during the last decades of the 20th C. ${ }^{5}$

In conclusion, in folktale - the oldest kind of literary tradition- we find both positive and negative aspects of the mythical functions. Most particularly, it is believed that the magical tales (fairytales) have been transformed by traditions of initiation rites of primitive societies, which reflect the stages of human maturity. In the structure of the story unfolds the structure of the ceremony. ${ }^{6}$

\footnotetext{
${ }^{5}$ More details see the following sources:

Alexiadis, R.N. Comments on Karpathian tales of his collection in Karpathiakai Studies, I.: 213-215., [in Greek], 1979.

Anagnostopoulos, B.D-Liapis, K.. Folk tales and storytellers in Greece., [in Greek], Athens: Kastaniotis. 1995.

Anagnostopoulos, B.D. The art and technique of the story. [in Greek], Athens: Kastaniotis, 1997.
}

Bruner, J. Acts of meaning (transl. H. C. Rokos. Kalomoiris). [in Greek], Athens: Greek Letters, 1997.

Bruner, J. Creating stories (transl. B.. Tsourti-K. Polydaki-C. Kougioumtzakis). [in Greek], Athens: Greek Letters, 2002. Kakridis, TH.I. Ancient Greek tales, the Inspection of children's literature. Volume 3, [in Greek], Athens: Kastaniotis, 1988. Kaplanoglou M. Greek Folk Tradition. The stories in magazines for children and young people from 1836 to 1922. [in Greek], Athens: Greek Letters, 1988.

Kaplanoglou M., Fairytale and narration in Greece: An old art in a new era. The example of the narrators of the islands and of the refugee communities of Asia Minor Greeks. [in Greek], Athens: Patakis, 2002. Kyriakides, S.. Greek folklore, Part A. [in Greek], Athens: Monuments of speech, (1st ed. 1922).

Lucas, D.. Modern Greek folklore texts. [in Greek], Athens, 1957.

Boom, N., The garden to the lost tales: Greek folk culture and tradition, [in Greek], Athens: Estia I.D.Kollarou, 1979.

Great, C., Introduction to Folklore, [in Greek], Athens 1967.

Meraklis, M., The folktale. Texts of tales, [in Greek], Athens: Greek Letters. Review Interdisciplinary library, 1999.

Chatzitaki- Kapsomenou, Ch. (Introduction and selection of texts)-The modern Greek folk tale, [in Greek], Thessaloniki / Library: Institute of Modern Greek Studies Foundation Manolis Triantafillidi, 2002.

${ }^{6}$ Rontari, G. (The Fantasy of Grammar). In the chapter of the book where "Propp's cards" are referred, the correlation of the rituals of primitive societies with the enchanting folktales are recorded. Specifically, we would describe the transformation of the creation of the enchanting folktale as the action firstly becomes narration and then word The initiation rituals turn into folktales, the holy into magical, terrific and supernatural. The primitive child becomes the hero of the folktale. The initiation rituals lead to the preparation of the entering into the society. Children become adolescents and escape into the forest, like the hero of the folktale deserts the security of the family. Magicians daunt by their 


\subsection{Historical overview of the Folktale}

The birth of the tale came after the myth but both are based on the same morphological system. For example, the case of the Oedipus of Sophocles, which in ancient Greece was a myth, assumed a Christian character in the Medieval times, and the Saints became heroes, like San Andreas of Crete, who redeemed a grave sin with his great virtue. This same story was subsequently transformed to a tale, with its hero remaining anonymous and the narration losing its sacred character. Thus, the scenarios in the course of historical development may pass from one genre to another. Certainly, in today's social reality and based on the existing social formations and the degree of cultural development of the people, myths are impossible to exist (they were replaced by holy history and church narration), in contrast with the tale that proves to be timeless [18].

So, while the folktale seems unchanged and historically immutable (based on its formative elements such as resurrections, transformations, the abolishment of physical determinism, and the allowance for the most bizarre and imaginative situations), scientifically it is shown to be a multilayered genre that carries the traces of mostly all the historical periods during its century-long course.

Tradition, in the sense of the folk narrative, has a specific typology: it draws its subjects from Theology, geophysical phenomena, cultural or historical happenings, in which there can be recognized points of supernatural intervention. The narration is short with specific reference to the place and time of action.

The only tale that survives from antiquity is the tale of "Cupid and Psyche", which Apoulios (Roman writer) included in his work "Metamorphoses" in the $2^{\text {nd }}$ century AD. Tales with a folktale character are found in Homer, Herodotus, the tragic poets (Alcestis by Euripides) and fiction series such as the Argonauts, Hercules and Perseus. According to Andrew Lang, fairy tales existed since the 13th century BC in ancient Egypt.

The folktale was a symbol of childhood, innocence and simplicity with infinite adaptation options, with full freedom and beyond the need to reference any specific person, time or place. It is characterized by universality and diversity. At the same time, it reshapes and transforms while moving between vagueness, fantasy, magic and improbability; at the same time, it does not ignore the social reality of which it is a product.

Historically, folktale has undergone various conversions from being a rural folktale to becoming urban reading material. This conversion process had already started in Europe since the Renaissance and now traces a path of continuous interactions between words and folk elements.

One of the first collection of forty seven contemporary Greek tales was published by the Austrian philhellene and antiquity scholar Johann Georg von Hahn, (Copenhagen, 1879), under the title "Contes Populaires Grecs".

appearance, like the witches or magician or monsters threaten the hero of the folktale. The young people undergo a number of challenges, like the folktale heroes face many difficulties as the folktale unravels. The adolescents gradually initiate into the myths of the tribe and are granted the weapons (the holy bundle) as the heroes of the folktale are granted the magical presents. After the initiation, the young people go back to their families as adults bearing another name while the folktale hero comes back as an unknown person. The mature men are finally ready to get married and settle down, and the folk heroes are recognized and get married respectively.
Bernhard Schmidt (German philologist) had preceded him, having published a volume of Greek tales, traditions and folk songs under the title: «Griechische Marchen, Sagen und Volksliede», (Leipzig, 1877).

However, as Avdikos, E (1994) claims: "the indisputable value of the tale in all societies presents a universality that transcends the national limits and, therefore its study reveals stances and attitudes that answer to today's questions, as they played a determinative instructive role in the societies where they were created." Elements of tradition become part of tales oftentimes and hold specific roles in the plot of the tale or the folk song.

\subsection{The Greek Folk Song ${ }^{7}$}

The Greek folk song mirrors faithfully and completely the life, the morals, the emotions and the intellect of Greek people [26]. A collection of Greek folk songs «constitutes at the same time the true national history of modern Greece and the truest representation of the morals of its people [13]. The folk song is a spontaneous lyrical creation, the collections of which comprise national narratives, the "soul of the people", which condenses the substance of every people, by being an ontological and trans-historical element. It is therefore directly linked to a given place, time and persons and imaginative contrivances intertwined with historical or pre-historic elements of the oral tradition that are accepted as true.

The longstanding historic course of Hellenism fueled the creator of folk poetry with numerous stimuli, such as the pain of slavery and the pain for the Fall of Constantinople, the joy of winning the battle and the hope for liberation.

The initial interest in the Greek folk song originates in the respective German intellectual pursuits of romance.

The so-called Akritika songs (border songs) were created in the 9th and 10th C. AD., describing the epic struggles of warriors on the east edge of the Byzantine Empire known by the name "Akrites" [Frontiersmen], such as Armouris of Theophylactos, his son Andronicus, etc.). "Digenis Akritas ${ }^{8}$ " is the legendary heroic warrior (probable creation of a scholar of the time) whose reputation exceeded the geographical confines of Cappadocia -where it was created - and spread to Greece,

${ }^{7}$ More information on folk songs see the following sources:

Baud-Bovy Samuel, Chanson populaire grecque du Dodècanèse: Les texts, I. Genève: Les Belles Lettres, 1936. Kapsomenos, Q. The Cretan historical song, [in Greek], Athens: Foundation, 1979.

Kyriakides, St., The folk song. Synagogue studies. [in Greek], Athens: Hermes, 1978.

Pplitisss, Al., The folk song, [in Greek], Heraklion: University of Crete.., 2010.

Sifakis, Gr. Towards a poetics of Greek folk song., [in Greek], Heraklion: University of Crete, 1988.

${ }^{8}$ The text of the six or eight heroic songs first published in 1875 in Paris by Satha, Constantine and Emile Legrand, Les exploits de Digenis Akritas, d'apeès le manuscript de Trèbizonde. See also in:

Miliarakis, A.. Vasileios Digenis Akritas, in the men Found manuscript., [in Greek], Athens, 1881.

Alexiou, S.. Vasileios Digenis Akritas and Ballad of Armouri, critical edition. [in Greek], Athens: Hermes., 1985.

More details see the following sources:

Thanopoulos, C.. Digenis Akritas Escorial and the Pontic Folk Song. Common typically morphological and stylistic elements of the poetic. [in Greek], Athens: Armos, 2012.

Ioannidis, S. Ed. Epic medieval manuscript of Trebizond, Vasileios

Digenis Akritas the Cappadocian. [in Greek].Istanbul, 1887. 
Cyprus and the Black Sea. The person of Digenis is the starting point in the formation of a new consciousness in the cycle of folk songs, and served as basis upon which a new cycle of folk poetry ("kleftika" songs) was built.

The types of moral and instructive folk poetry, such as "Spaneas", and satirical poetry such as the "Ptochoprodromos" followed. In Crete and the Aegean Islands, though, we have the blooming of the erotic folk song in the 15th-16th C. A work from this period is "Apokopos" by Bergadis ${ }^{9}$, and in the 17th century "Erotokritos ${ }^{10}$ " by Cornaros, Vincenzo, which assimilated the folk heritage, and "Erophile" by Chortatsis. Also, we have categories of folk songs of a timeless character as they pre-existed the 9th $\mathrm{C}$. and are found in Antiquity, but also in the post-Christian and the post -Byzantine eras. According to research, from Early to Late Antiquity, save the epic poetry of the Homeric times- there was a tradition of folk songs of a timeless character on marriage, love, daily work and death (mourning) ${ }^{11}$.

In the mid-18th C. and early 19th C., a new genre of folk songs under the name "kleftika" appeared in mainland Greece; these songs relate to the "armatolous and kleftes" (guerilla fighters against the Turkish occupation), and constitute a major milestone in the Greek cultural tradition. From the late 19th C., the folk song is the most authentic vehicle of the Greek folk culture and the sole educational means with which the peasants preserved their national identity and cultural character [30]. The historical folk song was called to contribute to the preservation of the Greek national identity after the Revolution, as the Greek identity was a notion in crisis, because of its affinity to its ancient past, unity and duration in space and time.

The folk song represents the direct and valid expression of the worldview and the ideology of the Greek countryside people. It also expresses the deepest bond between man and nature, which in the Greek Mediterranean mentality is defined as a relationship of balance and harmony and as a mother and son relationship. (Kapsomenos, Er.)

The first collection of our folk songs was published in two volumes by Claude Fauriel in the years 1824-1825 [13], but the best and most famous in the world yet is Nikolaos Politis's work: "Choices of the songs of Greek people.” All the great national poets of Greece based their work on folk songs, such as: Solomos, Palamas and Sikelianos.

Folk songs are divided into three categories: a) table songs, b) street songs, and c) dance songs. Modern folk poetry deals with the cycle of life: (birth- marriage - death) and its customary events (baptism, wedding party, community involvement, commemoration of death), and expresses collective experiences and individual feelings.

\subsection{Proverbs}

The category of "proverbs" is a kind of folk literature that has survived in education due to both its historical reference and its modern functionality. It is usually a brief

\footnotetext{
${ }^{9}$ Bergadis Cut, typografisi grow sugar. Venice, 1509.

${ }^{10}$ Cornaro, Vicenza, Erotokritos critical edition. Editing Alexiou, Stylianos, [in Greek], Athens: Hermes, 1980.

${ }^{1 "}$ Guy Saunier, Greek folk songs. The lamentations. Compilation, classification, study,[in Greek],, Athens: Nefeli, 1999.
}

aphorism in verse of the spontaneous folk wisdom and creativity that conveys a piece of advice given in a figurative, allegoric or literary way; proverbs are used in the present day as much in everyday speech as in the political and scholarly speech. They are characterized by vivid and rich imagery, while, most of the times, are presented in the form of couplets. Proverbs are divided into three categories: main proverbs, maxims (sayings) and proverbial expressions (linguistic idioms).

Many of the proverbs have originated from a) the Bible, b) historical events, c) ancient proverbs, maxims and sayings, d) speeches and aphorisms of historic people, e) folk myths or the verses of folk songs, and f) contact with other people, etc. [30].

Some proverbs contradict one another, such as: "hasten slowly". One class of proverbs serves a system of moral and social virtues based on religion. For example, "God gives much to the one who gives." There are also proverbs related to work, such as: "industriousness is happiness and life; laziness is death and the source of bad things." We observe that work is rated highly both in ancient Greece and in the Bible and in the continuum of history. Work is the means by which Greek immigrants preserved their culture.

Meraklis, M. produced a wonderful study with the title «Proverbs of Greek and other people in the Balkan (Comparative study)", which reveals the mental connection between the Balkan people based on a great number of common proverbs. Meraklis used as his starting point the corresponding study of Bulgarian ethnographer Nikolai Ikonomof [16] and enriched his project with Greek folklore material that was published. Proverbs are the most vivid elements of folk art even in our time and constitute an important combination of simplicity and depth [20] ${ }^{12}$.

A characteristic of proverbs in general is the fact that they are flexible to adjust to new environments and conditions, usually by the modification of old proverbs, so that they relate to society, acquire the characteristic of timeliness or even assist with advertisements. These are called anti-proverbs ${ }^{13}$.

\subsection{Legend}

Legend is a narrative of human actions that are often misrepresented by folk imagination. The word originally meant the noise created by many voices and then the event everybody talked about. Just like the other types of folk literature, legends grew from oral tradition; writers

\footnotetext{
${ }^{12}$ About proverbs see the following sources: Alexiadis, Minas, and proverbial gnomikos why Greek politicians. Samples of the Athenian type. Scientific Annals of the University of Athens, [in Greek], (20082009) p.45-66.

Avdikos Evaggelos, Grecian Riddle-Jokes: Functional Features of a New Minor Form. Folklore: Electronic Journal of Folklore, http://www.folklore.ee/folklore/authors/eavdikos.htm 2010. Doulaveris, Aristides, Greek proverbial ground, [in Greek]. Thessaloniki: Stamoulis, 2010.

Lucas, Dimitrios, Introduction to Greek folklore, [in Greek]. Athens: National Bank of Greece Cultural Foundation, 1985, p. 116-129. Loukatos, Dimitrios, Le Proverbe dans le conte, (1908-2003). IV. International Congress for folk- narrative research, Athens, 1964. Mieder, Wolfgang., Proverbs, A Handbook, New York / Washington: Peter Lang Publ., 2012.

${ }^{13}$ More Alexiadis, Minas, Anti-proverbs in Athenian newspapers, the print media and popular culture: Novel folklore, [in Greek], Athens: Kardamitsa, 2011, p.83-124.
} 
sometimes borrowed legends from oral tradition and decorated them with artistic forms.

The legend really flourished during Middle Ages since it could describe amazing facts. Later on, it blended with other kinds of narration of real or imaginary events that referred to persons, places or historical times. In this wider meaning the legend can be distinguished by the historical narration, the folktale as by the myth as well. However, the difference between legend and religious myth (myth about gods- ike Olympians' gods- and heroes) is less obvious.

A general criterion of distinction lies in the fact that while the legend is based on human things and events, the religious myth revolves around superhuman beings. It, therefore, lies outside of the human history. Besides human history, there's a special category that is called "hagiographic legends", the subject of which is the life and work of the Saints (such as legends in the Middle Ages.) $)^{14}$.

Legends are very dear to children for they cultivate their imagination, as their heroes are typically historical figures. We can mention the legends of Alexander the Great and his mermaid sister mermaid, the legends of Constantine Paleologos (e.g. the legend of the Marbled King.)

Our reaction to legends is shaped and expressed in words; this constitutes the form of conscience. But the spirit-creation of the legend includes the expression of feelings and reminds one that a large part of the legend comes from the collective unconscious.

In each civilization, myths, legends and folk traditions characterize the crystallization of the moral and mental heritage that is inherited through the artistic, historic and family tradition, thereby creating and developing the branches of the conscience of the spirit of the Race.

\section{Conclusions}

The content of folk literature in general, can constitute, on the one hand, the cultural matter for the formation of the contemporary identity of the child within a context of a globalized society that clearly overrated the technological advancements.

The oral tradition of creation was based on the cultivation of memory, logic and originality through repetition (not only from fixed patterns and stereotypes) and through the expressions that play a role in the ritual text and are easily remembered due to their repetition, rhythm, alliteration or continuous meter and articulation.

However, all kinds of folk literature present common or similar elements in the bibliography of all nations, a phenomenon that can be explained on account of the fact that all people are descendants of a deeper collective unconscious, the archetypes. In folk literature, the archetypes are reflected in their simplest, most concise forms, which then in turn produce the "archetypal images" that were found in tales, myths, dreams, the arts, religion and in philosophy of all times and all peoples [17].

\footnotetext{
${ }^{14}$ More information on legends in view: Anagnostopoulos, BD (1999) Folk legends and traditions for children. Anthology, second edition, [in Greek], Athens: Kastaniotis.
}

Consequently, myths are a direct expression of the collective unconscious and we find them in similar forms and in literary products of all peoples of all times.

So, if man loses his fictional capacity, he then loses his contact with the creative forces within himself. Religion, poetry, folk legends and tales exist due to the same capacity.

Therefore, the contribution of folk literature is important to education in general, as a tool of transmission of cultural material that includes elements such as the role of myths of origin, historical memories and cultural differences such as religion, customs, traditions, languages and institutions. From the standpoint of teaching, folk literature can function as a developed narrative that helps to shape the cultural identity of the child and the development of his written and spoken language.

It is also one of the most appropriate fields for the materialization of cultural meetings and the promotion of common cultural elements among peoples; folklore has already been used in USA since the '70s in order to study social phenomena $[8,9]$.

As we said before, folk literature is not a static phenomenon but transforms through the social environments by the people of every era and the institutions it assimilates. It transfers therefore the historical experience and the common heritage of values and symbols, as there is a vibrant process which engages its creators and relates to specific historic realities and expresses and regulates social relations.

Today, these literary genres convey a wisdom that can give meaning to the western way of thinking in a Europe that lacks spiritual and existential meaning. We should keep in mind that the international vision of today, in light of the global community, is the cultural coexistence of people with diverse cultural identities.

\section{References}

[1] Antti Aarne. The Types of the Folktale: A Classification and Bibliography. The Finnish Academy of Science and Letters, Helsinki, 1961. AaTh (2004). The types of Folktale. A classification and Bibliography. International folktales Uther, Hans-Jörg.Part 1: Animal tales, Tales of magic, Religions and realistic tales. Helsinki. F.F.C. 284. AaTh (2004). The types of Folktale. A classification and Bibliography. International folktales Uther, Hans-Jörg Part 2: Tales of stupid ogre, anecdotes and jokes and formula tales. Helsinki. F.F.C. 285. AaTh (2004). The types of Folktale. A classification and Bibliography. International folktales Uther, Hans-Jörg (2004). Part 3: Appendices. Helsinki. F.F.C. 286

[2] Bambiniotis, Georgios. Theoretical Linguistics. Introduction to modern linguistics, [in Greek], Athens, 1998.

[3] Bettelheim, Bruno, The Uses of Enchantment: The Meaning and Importance of Fairy Tales, Knopf, New York, 1976.

[4] Boas, Franz. "Mythology and folk-tales of the North American Indians". Journal of American Folklore, Vol. 27, No. 106, Oct.Dec. 1914 pp. 374-410.

[5] Bruner, J. Acts of meaning (translated Rokos H.-C. Kalomoiris), [in Greek], Athens: Greek Letters, 1997.

[6] Campbell, Joseph-John. The Power of Myth with Bill Moyers and editor Betty Sue Flowers, Doubleday, hardcover: 1988.

[7] Cooper, JC. The wonderful world of fairy tales: allegories of the inner life, the road to maturity, [in Greek], Athens: Thyme, 1983.

[8] De Caro, Francis, A. Studying American Folklore in Printed Sources, to: Handbook of American Folklore (ed. Richard M. Dorson), Indiana University Press, Bloomington, 1983.

[9] Dorson, Richard M. The Use of Printed Sources, to Folklore and Folk life: An Introduction, Indiana University Press, Chicago and London, 1972. 
[10] Eliade, Mircea. Myth and Reality. Trans. Willard R. Trask. New York: Harper \& Row, 1963.

[11] Erikson, E.. Identity, youth, and crisis. New York: Norton, 1968.

[12] Frazer, James G. The Golden Bough 3rd edition: 12 volumes (1906-15; 1936) New York: Macmillan one-volume bridgement, 1922.

[13] Fauriel, Claude-Charles. Chants populaires de la Gréce moderne (1824-1825), to Lukatos, Dimitrios The first singing of Twenty (texts by Friel), New home, Tribute to '21, Christmas 1970, No. 1043: 246-59.

[14] Greimas, A. J. Structural Semantics: An Attempt at a Method, trans. D. McDowell, R. Schleifer, and A. Velie. Lincoln: University of Nebraska Press, 1983.

[15] Hobsbawm, E.. Nations and Nationalism since 1870 until today, translated HRIS. Nantis, [in Greek], Athens: Kardamitsa, 1994. Nations and Nationalism since 1780: Programme, Myth, Reality (Canto Classics)

[16] Ikonomof, Nikolai. Balkanska Narodna Madrost, usporedici na Balgarski, srabski, turski, rumanski, gracki I albanski, poslovici i pogovorski, (edition of the Bulgarian Academy of Sciences), Sofia, 1968.

[17] Jung, Carl-Gustav. Man and his symbol, [in Greek], Athens: Arsenidis, 1980.

[18] Le Goff, Jacques. Literature: texts et documents: moyen age XVII siècle, Paris: Nathan c, 1988

[19] Livo \& Rietz. Storytelling: Process and Practice, Libraries Unlimited, Colorado, 1986-Gersie, Al. Earthtales: Storytelling in Times of Change, Green Print, London, 1992.

[20] Meraklis, M.. What is folk literature, [in Greek], Athens: Modern era, 1988.

[21] Papanoutsos, E., The Tale, Ephemera, News, untimely, Athens: Ikaros, 1980.
[22] Parés,M., Maicas,I.. The construction of reality from the media, Athens, Alexandria, 1997.

[23] Piaget, Jean. Psychology and pedagogy1896-1980. [in Greek] Athens: Livanis, 1999. Original title: Psychologie et pédagogie.

[24] Pashalidis G.. Cultural identity as a right and as a threat. The dialectic of identity and ambivalence of criticism, in: Konstantopoulos, C., Marantou-Alifanti, L, et al, op cit, 80. [in Greek].

[25] Politis,N.. Studies on the life and language of the Greek People. Tradition, Volume II, formally, [in Greek], Athens: Sakellariou / Library Maraslis 1904.

[26] Politis, N.. Selection from the songs of Greek people. [in Greek], http://anemi.lib.uoc.gr/metadata/e/4/4/metadata74beb76ecf59dc77ae553047b33d5937_1272879993.tkl, 1914.

[27] Propp, Vladimir J.. Theory and History of Folklore Minnesota: University of Minnesota Press, 1984.

[28] Strauss-Levy, Caude. «The Structural Study of Myth» Journal of American Folklore, t.68, No. 270, 1955. Printed in book form in French: Anthropologie structurale, 1958 Anthropologie structurale II, 1973, Paris Plon c: 1973-1974).

[29] Stavrou P. Ekaterina. The folk literature and its contribution to the education of handicapped children and children with special educational needs, [in Greek], University of Ioannina-Greece, 2012. http://hdl.handle.net/10442/hedi/28463

[30] The Greek Folk Tradition (collective volume), scientific and general layout: Avdikos, Ev. [in Greek] Athens: Alexander, 2014.

[31] Triantou, If.. From the theory to literature's meaning, Greek, Patras: Diapolitismos [in Greek].

[32] a) Uther, Hans-Jorg. Behinderte in popularen Erzahlungen-studien zur historischen und erzahlforschung, Walter de Gruyter. Berlin. New York, 1981. b) Uther, Hans-Jörg. The Types of International Folktales: A Classification and Bibliography. Based on the system of Antti Aarne and Stith Thompson. FF Communications no. 284286. Helsinki: Suomalainen Tiedeakatemia, 2004. 